\title{
Migration, Mobility and the Making of a Global Europe
}

\author{
Tara Zahra
}

Homer J. Livingston Professor of History, University of Chicago, 1126 E. 59th Street, Chicago, IL 60616, United States tzahra@uchicago.edu

In 2017-18, the Chinese artist Ai Weiwei created a special installation addressing the refugee crisis in Prague. 'Law of the Journey' consisted of an enormous black inflatable raft, crowded with inflatable rubber people wearing lifejackets. Their human forms were clear, but they lacked faces. The raft hung from the ceiling at an angle, casting a dark shadow over a list of quotations from thinkers and writers, beginning and ending with two locals: Franz Kafka and Václav Havel. A few isolated rubber tubes floated on the concrete floor next to the raft, with rubber humans reaching out to be saved. The exhibit conveyed both the desperation of the migrants and the inadequacy of the response.

I first saw Ai Weiwei's installation in September 2017. When I stepped outside the exhibition hall, the (pre-COVID) city was crowded with tourists drinking cheap beer. There was little sign of the migrant flows that were being depicted inside. So why did Ai choose Prague for his installation? And what does a medium-sized central European city have to do with migration, mobility and the global history of Europe? The installation site itself offers some clues. The exhibition was housed at the Veletržní Palác, the 'trade fair palace'. When it was constructed in the 1920s, this vast modernist building, occupying a whole city block, reflected the ambitions of liberals in interwar Czechoslovakia to become the trade centre of Europe, a bridge between East and West. The Great Depression and the Second World War dashed those hopes. The hall remained empty for a while, until it was put to use as an assembly point for Jews being deported to the Theresienstadt (Terezín) ghetto and concentration camp.

Moving beyond the installation site, the Bohemian Lands/Czechoslovakia/Czechia have been made and remade many times over by global migration. Tens of thousands of emigrants set out for North America in the mid-nineteenth century. The exodus prompted some early Czech nationalists to lament the loss of precious human capital, but others began to imagine emigrants as agents of colonial expansion. Some opponents of emigration meanwhile worried that migrants would be treated as nonwhite 'slave' or 'coolie' labour. In the 1930s, Jews from neighbouring Germany and Austria fled to Czechoslovakia, hoping to find a safe haven in one of Europe's last-standing democracies. Soon after, the Nazis dismembered the state and Czechoslovak Jews scattered to all corners of the earth, seeking shelter in places like Palestine, Shanghai and the Dominican Republic, as well as North America and Great Britain. The direction of these migratory movements was not isolated from global colonial and racial politics. For example, one of the only states to welcome Jewish refugees, the Dominican Republic, did so because dictator Rafael Trujillo hoped to import 'racial elements both capable and desirable' after having recently massacred 15,000 Haitians. Some Jews objected to Jewish resettlement in the tropics out of fear of racial 'degeneration' and intermarriage; others argued that they would bring European 'civilisation' and 'culture' to places like Palestine and British Guiana. In the decades after the Second World War, several hundred thousand Czechs and Slovaks fled communism. They often acquired visas to relocate in Western Europe, North America and Australia more easily than migrants from outside of Europe. This was not simply because of the political dynamics of the Cold War, but because they were perceived to be white and European, and hence more 'assimilable' than migrants from outside of Europe. Later, the communist regime began to recruit Vietnamese guest 
workers to Czechoslovakia; today there is a community of around 60,000 people of Vietnamese origin in the Czech Republic. ${ }^{1}$

When I visited Ai Weiwei's installation, the tour guide suggested that the artist had chosen Prague because Czech people were particularly receptive to his message. The Czech Republic, he claimed, had a historic reputation for being one of the most liberal and inclusive states in Europe. ${ }^{2}$ But, during the refugee crisis of 2015-17, only twelve refugees were accepted for resettlement in the Czech Republic, in open defiance of European Union quotas. Later, in the summer of 2018, the Czech government stopped issuing long-term residency and employment visas to Vietnamese migrants, citing alleged security risks. ${ }^{3}$ Like other European cities, Prague has been both a refuge and a prison for migrants; a city of opportunity and exclusion. This reflects the dominant theme of Czechoslovak history until 1948, which has traditionally been the story of nationalisation and national conflict within the borders of the Habsburg Empire and Czechoslovakia. Migration appears mostly as a violent coda: the expulsion of three million Germans at the end of the Second World War marks the brutal end of the history of multinationalism in the region, and immobility is one of the dominant motifs of Czechoslovakia's post-1948 history. And yet, like many places in Europe where migration might appear marginal to national history, there are few moments that were not shaped by the history of migration and mobility. This seemed to be the deeper message behind Ai's installation: it was a plea to the Czechs to remember the important role migration played in their own history.

\section{Defining Europe through Migration}

In the last several decades, historians of migration have collectively made the case that it is impossible to understand the history of 'Europe' without reference to migration, including migration to and from places located (imaginatively or institutionally) 'outside' of Europe. ${ }^{4}$ Most recently, Peter Gatrell's Unsettling of Europe begins with the claim that 'without putting migration and migrants at its heart, the history of Europe since the end of the Second World War is incomplete'. He goes on to retell the history of major postwar European political developments, including postwar reconstruction and economic recovery; the formation of the European Union; the tensions of the Cold War; decolonisation; and the collapse of communism from the perspective of migration history. ${ }^{5}$ Philipp Ther's The Outsiders, originally published in German, makes a similar claim regarding the centrality of refugeedom to the history of Europe, also expanding the frame of European history to include the places to which refugees fled and the places from which they came, including the Americas, the Middle East, South Asia and North Africa. ${ }^{6}$

These arguments - that global migration is central to the history of modern Europe - might seem uncontroversial to professional historians. But the gap between professional historians and public debate has widened so much that these histories are urgently needed. They speak back to the

1 Tara Zahra, The Great Departure: Mass Migration from Eastern Europe and the Making of the Free World (New York: W.W. Norton, 2016). On the Dominican settlement, see Marion A. Kaplan, Dominican Haven: The Jewish Refugee Settlement in Sosúa, 1940-1945 (New York: Museum of Jewish Heritage, 2008); on Jewish refugees in Czechoslovakia, see Kater`ina C`apková and Michal Frankl, Nejisté útoc ${ }^{`}$ is $^{\vee} e^{\vee}$ : $C^{\vee}$ eskoslovensko a uprchlíci pr`ed nacismem 1933-1938 (Praha: Litomys`l: Paseka, 2008). On Vietnamese migrants in Czechoslovakia, see Alena Alamgir, 'Socialist Internationalism at Work: Changes in the Czechoslovak-Vietnamese Labor Exchange Program, 1967-1989', PhD dissertation, Rutgers University, 2014; Tereza Freidingerová, Vietnamci v Česku a ve světě: migrační a adaptační tendence (Prague: Kosmas, 2014).

2 On the idea of Czech exceptionalism, see especially Andrea Orzoff, Battle for the Castle: The Myth of Czechoslovakia in Europe, 1918-1948 (Oxford: Oxford University Press, 2009).

3 Chris Harris, 'Fact Check: How Many Refugees Has Each EU Country Taken In?', Euronews, 26 Sept. 2017, online; 'Prague Suspends Admission of Work Visa Applications by Vietnamese', Prague Daily Monitor, 20 July 2018, online.

4 See, most recently, Peter Gatrell, The Unsettling of Europe: How Migration Reshaped a Continent (New York: Basic Books, 2019); Philipp Ther, The Outsiders: The History of Europe as a Continent of Refugees, trans. Jeremiah Riemer (Princeton: Princeton University Press, 2019).

5 Gatrell, The Unsettling, 3.

6 Ther, The Outsiders, 16-21. 
arguments made by right-wing and populist movements that countries such as Poland, Hungary, France, Italy, Britain or Germany are not or should not be 'nations of migrants' and that the contemporary 'crisis' around migration represents a threat to 'European civilisation'. Crucially, both Gatrell and Ther take their narratives to the present day, demonstrating how contemporary migration panics build on anti-migrant fears and tropes from the past - and showing how successive generations of migrants have, in Gatrell's words, been 'intrepid' in their efforts to 'negotiate obstacles, try to stay safe, support themselves, and realize their dreams in new settings, without necessarily severing ties to the place of their birth'?

In this essay I seek to expand on the argument that global migration has 'made' Europe, and to reflect on future directions for the field. This is more than a matter of showing that mobility has transformed European societies (although it has). Migrants do not land in static 'cultures' - the places they come from and the places they arrive to are always in the process of changing. ${ }^{8}$ Rather, I argue that mobility and migration have been central to changing understandings of who is European, where Europe is located and what Europe means.

Why speak of 'mobility' or 'movement' rather than migration alone? Historians of migration have gravitated toward the term 'mobility' in part because it captures the multi-directionality of movement. It includes people not often thought of as 'migrants' but whose movements have transformed Europe. These include sailors and colonial officers who moved from post to post, shaping imperial ideologies and practices on board; colonial settlers, explorers, entrepreneurs, missionaries and scientists, as well as slaves and domestic servants; experts who moved between Europe and Asia, Latin America and Africa, shaping the dynamics of the global Cold War. ${ }^{9}$ It includes vagabonds, travellers and nomads, whose wandering was believed to threaten European sovereignty and civilisational projects. The study of 'mobility' also takes the journey itself seriously, rather than simply treating it as 'empty time' between here and there. Increasingly scholars of mobility are focusing on port cities, steamships, train stations, airports, highways and hotels, where travellers interact and border regimes are put into practice. While we must be careful not to obscure the relations of power, inequality and violence that often structure movement, 'mobility' captures a broader range of migration histories and can call into question the assumptions that surround the term 'migrant'.

In exploring how migration and mobility made Europe, we might start with the continent's physical and material history, including its environment, its material culture and its borders. In the

7 Gatrell, The Unsettling, 13.

8 Dirk Hoerder, Cultures in Contact: World Migrations in the Second Millennium (London: Duke University Press, 2002$), 1$.

9 On the binary between 'migration' and 'mobility', see Jan Lucassen and Leo Lucassen, 'Measuring and Quantifying Cross-Cultural Migrations: An Introduction', in Jan Lucassen and Leo Lucassen, Globalising Migration History: The Eurasian Experience (Leiden: Brill, 2014), 9-11; on colonial soldiers, see Charles Fawell, 'In-Between Empires: Travel, Space, and Sovereignty Along the Maritime Routes of Imperial France, c. 1870-1930', PhD dissertation, University of Chicago, 2021; on development workers during the Cold War, see Young-Sun Hong, Cold War Germany, the Third World, and the Global Humanitarian Regime (Cambridge: Cambridge University Press, 2015). On expatriates, see Nancy L. Green, The Other Americans in Paris: Businessmen, Countesses, Wayward Youth, 1880-1941 (Chicago: University of Chicago Press, 2014); on entrepreneurs, see Steven Press, Rogue Empires: Contracts and Conmen in Europe's Scramble for Africa (Cambridge, MA: Harvard University Press, 2017). On care workers and domestic servants, see among others, Dirk Hoerder, Elise van Nederveen Meerkerk and Silke Neunsinger, Towards a Global History of Domestic and Caregiving Workers (Leiden: Brill, 2015); on slavery, see David Eltis, Stanley L. Engerman, Seymour Drescher and David Richardson, eds., The Cambridge World History of Slavery, vols 1-4 (Cambridge: Cambridge University Press, 2011-17).

10 For a critique of the 'mobilities' paradigm, see Pamela Ballinger, 'Beyond the Italies? Italy as a Mobile Subject', in Ruth Ben-Ghiat and Stephanie Malia Hom, eds., Italian Mobilities (New York: Routledge, 2015), 20-45. On the experience of mobility and migration, see among others, Valeska Huber, Channelling Mobilities: Migration and Globalization in the Suez Canal Region and Beyond, 1869-1914 (Cambridge: Cambridge University Press, 2013); Tobias Brinkmann, ed., Points of Passage: Jewish Transmigrants from Eastern Europe in Scandinavia, Germany, and Britain 1880-1914 (New York: Berghahn Books, 2013); Orvar Löfgren, 'Motion and Emotion: Learning to be a Railway Traveler', Mobilities, 3 (2008), 331-51; and Phillip Vannini, ed., The Cultures of Alternative Mobilities: Routes less Travelled (London: Routledge, 2009). 
Bohemian lands, for example, Eagle Glassheim demonstrates how the expulsion of millions of Germans facilitated the communist state's devastating exploitation of the Czechoslovak borderlands for coal mining. Forced immobility has also had an effect on Europe's landscapes, as Astrid Eckert's work on the Iron Curtain reveals. She discusses how the militarised 'no-man's land' between East and West Germany had an unintended beneficiary: ground-breeding birds that flourished in the absence of human and industrial habitation. But Eckert also reminds us of the destruction of forests and ecosystems that accompanied the border's construction; the deadly consequences of minefields for the migration of mammals (and border dogs) and the negative effect of the border on local wetlands. Current events strongly suggest that future histories will focus on the intersections of environmental change, mobility and immobility. The COVID-19 pandemic and the unprecedented halt to global mobility in 2020-21 clearly had both positive and negative environmental consequences that remain for future scholars to untangle. And historians will doubtless soon be writing much more about the history of climate refugees. ${ }^{11}$

In the realm of material culture, meanwhile, scholars have shown how migration and return migration have shaped the architecture, domestic interiors, culinary practices and other aspects of the material world in Europe, and in the countries from which migrants came (and to which they often returned). This process of mutual transformation makes it even more challenging to delineate who or what is 'European' and even where 'Europe' is located. And it may also provide clues to understanding the rise of populist nationalism, which often focuses on 'preserving' what is claimed to be authentic national material culture. As Leora Auslander has argued, the ways in which migration has transformed the material and sensorial environment of cities - architecture, smells, sounds and tastes has fuelled anti-migrant politics since the $1970 \mathrm{~s}^{12}$

Most obviously, the political boundaries of states and the imagined frontiers of Europe were shaped by anxiety over migrants and the pathogens they were believed to carry. The very first fortified sanitary cordon was erected between the Habsburg and Ottoman empires in the eighteenth century in order to prevent the spread of disease. It was widely seen as a boundary between Europe and the Orient as well as a barrier against epidemics. In the late nineteenth century, steamship companies and state officials erected 'sanitary' stations along German frontiers to prevent the spread of epidemics and control the movement of (often unwanted) migrants from Eastern Europe across the European continent. In doing so they reinforced an imagined divide between Eastern and Western Europe that had been created during the Enlightenment. ${ }^{13}$ The period of mass displacement after the Second World War was another moment when the fate of migrants was linked directly to the reconstruction of what was called 'European civilisation'. The massive displacement of millions of POWs, forced labourers, Jewish victims of Nazi persecution, refugees from fascism and communism and even (or especially) children separated from their parents was widely understood in terms of a crisis of European civilisation: the reconstruction of Europe was, in turn, believed to require the repatriation and settlement of these migrants, their reunification with families, homes and homelands, or resettlement abroad. ${ }^{14}$

11 For a pioneering example of work linking migration and the environment, see Sunil S. Amrith, Crossing the Bay of Bengal: The Furies of Nature and the Fortunes of Migrants (Cambridge, MA: Harvard University Press, 2015).

12 Leora Auslander, 'Negotiating Embodied Difference: Veils, Minarets, Kippas, and Sukkot in Contemporary Europe', Archiv für Sozialgeschicte 51 (2011), 401-18; on migration and material culture see also Leora Auslander and Tara Zahra, Objects of War: The Material Culture of Conflict and Displacement (Ithaca, NY: Cornell University Press, 2018); Hans Peter Hahn and Friedemann Neumann, eds., Das neue Zuhause. Haushalt und Alltag nach der Migration (Frankfurt: Campus Verlag, 2019).

13 Larry Wolff, Inventing Eastern Europe: The Map of Civilization in the Mind of the Enlightenment (Palo Alto, CA: Stanford University Press, 1994); Paul Weindling, Epidemics and Genocide in Eastern Europe, 1890-1945 (Oxford: Oxford University Press, 2000).

14 See among others Paul Betts, Ruin and Renewal: Civilizing Europe after World War II (New York: Basic Books, 2020); Atina Grossmann, Jews, Germans, and Allies: Close Encounters in Occupied Europe (Princeton: Princeton University Press, 2007); Silvia Salvatici, Senza casa e senza paese. Profughi europei nel secondo dopoguerra (Bologna: Il Mulino, 2008); G. Daniel Cohen, In War's Wake: Europe's Displaced Persons after World War II (Oxford: Oxford University 
Another way that Europe and 'European civilisation' has been constructed through mobility is in discussions around European ideals of gender, sexuality and race. Antoinette Burton famously demonstrated the extent to which European colonialism was legitimated by the mission of middle-class, European feminists to 'liberate' and 'civilise' non-European women by bringing European gender norms to the colonies. This was an imperial project buttressed by the migration of missionaries, female teachers, single women and wives to serve a civilising and rescue mission. In the process they defined what European gender and family relations should look like. ${ }^{15}$ Beginning in the late nineteenth century, anxieties about the emigration of single women from Eastern Europe to North and South America and the Ottoman Empire were channelled into a moral panic around sex trafficking, resulting in efforts to legally restrict female migration. Sensationalist accounts of the 'white slave trade' not only served to police female mobility and sexuality, however: they also reinforced the status of these female migrants - Jews, Poles and others from Europe's imagined peripheries - as 'white' Europeans. To the present day both the ideal of a unified Europe and the geographic hierarchies underpinning that construction are projected onto the bodies of migrant women. As Anca Parvelescu argues, the post-socialist traffic in East European women as sex and care workers has reinforced Eastern Europe's peripheral status within Europe while simultaneously signalling European integration. ${ }^{16}$

Europe's obsession with and anxiety about the family lives of migrants has always reflected debate over European norms of gender, sexuality and family as much as those of migrants. ${ }^{17}$ In her work on postwar West Germany, Lauren Stokes shows that migrants from southern Europe were stigmatised in the 1950s for failing to conform to the model of the 'traditional' nuclear family, which included a stay-at-home mother and excluded extended family. In more recent decades, ironically, immigrant families have been stigmatised throughout Europe for being oppressive to women and insufficiently 'modern'. ${ }^{18}$ In the French context, Joan Scott links French debates over the integration of Muslims in French society to anxieties about gender and sexuality, while Todd Shepard has examined the image of the 'Arab man' in relationship to the sexual revolution of the 1960 s and 70 s. $^{19}$ Not coincidentally, right-wing populists in Poland and Hungary have recently denounced efforts to advance women's rights (for example through their opposition to the Istanbul Convention of 2012 and through restrictions on reproductive rights), as well as the notion that gender is a constructed social category, as an imperialist imposition by European institutions ('an Ebola from Brussels'). This continues to provide negative reinforcement of the alleged link between Europe and 'progressive' gender values. ${ }^{20}$

At a more concrete level, regulating European migration - deciding who can come to and stay within the borders of the European Union - has entailed legally defining the European family. As

Press, 2011); Tara Zahra, The Lost Children: Reconstructing Europe's Families after World War II (Cambridge, MA: Harvard University Press, 2011).

15 Antoinette Burton, Burdens of History: British Feminists, Indian Women, and Imperial Culture, 1865-1915 (Chapel Hill: University of North Carolina Press, 1994).

16 Anca Parvulescu, The Traffic in Women's Work: East European Migration and the Making of Europe (Chicago, IL: University of Chicago Press, 2014), 40; on sex trafficking from Eastern Europe and emigration see also Keely Stauter-Halsted, The Devil's Chain: Prostitution and Social Control in Partitioned Poland (Ithaca, NY: Cornell University Press, 2015); Nancy Wingfield, The World of Prostitution in Late Imperial Austria (New York: Oxford University Press, 2017); Zahra, The Great Departure, chs 1-2.

17 See among other works Linda Guerry and Françoise Thébaud, eds., Dossier 'Femmes et genre en migration', Clio. Femmes, Genre, Histoire, 51 (2020); Linda Reeder, Women in White: Migration and the Transformation of Women in Rural Sicily, 1880-1928 (Toronto: University of Toronto Press, 2003); Camille Fauroux, Produire la guerre, produire le genre. Des Françaises au travail dans l'Allemagne nationale-socialiste (1940-1945) (Paris: Editions EHESS, 2020); Suzanne M. Sinke, 'Gender and Migration: Historical Perspectives', The International Migration Review 40 (2006), 82-103.

18 Lauren Stokes, 'Fear of the Family: Migration and Integration in West Germany, 1955-1998', PhD dissertation, University of Chicago, 2016.

19 Joan Scott, The Politics of the Veil (Princeton: Princeton University Press, 2007); Todd Shepard, Sex, France, and the Arab Man, 1962-1979 (Chicago: University of Chicago Press, 2018). See also Judith Surkis, Sex, Law, and Sovereignty in French Algeria, 1830-1930 (Ithaca, NY: Cornell University Press, 2019).

20 Elżbieta Korolczuk and Angieszka Graff, 'Gender as "Ebola from Brussels": The Anticolonial Frame and the Rise of Illiberal Populism’, Signs: Journal of Women in Culture and Society, 43, 4 (2018), 797-821. 
policies privileging family reunification were introduced in the 1970s, debates erupted over who counted as an immediate family member, how to discern a 'real' from a 'fake' marriage, and under what conditions migrants had the right to bring spouses, children or parents to live with them in Europe. All of these debates were shaped by specific national histories, including colonial and postcolonial histories, religious histories and economic systems, but they increasingly played out on a European level, through conferences and collaboration within the European Union. ${ }^{21}$

\section{Global Histories of Europe}

Until recently, most European migration history had surprisingly little to do with global history. The field consisted mostly of local, national or bi-national histories of specific migrant communities. Most histories of European migration or mobility were understood as interventions in nationally or ethnically-defined fields or regional histories, rather than global or even transnational history. ${ }^{22}$ Sometimes these preoccupations reflected progressive political goals: to demonstrate the contributions made by migrants to national histories; illuminate how migration has shaped constructions of nationhood and public policy; to challenge the notion that states were not 'immigrant nations'; or to write the history of minority groups whose histories had been overlooked or neglected. ${ }^{23}$

Today historians of Europe are more interested in situating Europe in a global context, but what do we stand to gain by integrating European migration history more fully into the field of global history, and vice-versa? It depends in part on how you define 'global history'. Many recent works advertised as 'global' histories of migration are synthetic volumes that attempt to compare multiple migration 'systems' or 'networks' across time or space, an approach intended to be 'global' by aggregation. These efforts are extremely valuable, but can a global history of European migration be more than history that examines movement to and from Europe and every corner of the globe? ${ }^{24}$

Lynn Hunt has warned that global history risks privileging the history of macroeconomic processes, neglecting cultural and social history as well as the non-economic forces that have shaped history. ${ }^{25}$ While it would be impossible (and undesirable) to write a global history of migration without reference to global capitalism, migration history does offer entry points into Europe's global history from a

21 Stokes, Fear of the Family; Martha Gardner, The Qualities of a Citizen: Women, Immigration, and Citizenship, 1870-1965 (Princeton: Princeton University Press, 2005); Catherine Lee, Fictive Kinship: Family Reunification and the Meaning of Race and Nation in American Immigration (New York: Russell Sage Foundation, 2013).

22 On the 'methodological nationalism' of migration history, see Andreas Wimmer and Nina Glick Schiller, 'Methodological Nationalism and Beyond: Nation-State Building, Nationalism, and the Social Sciences', Global Networks, 2, 4 (2002), 301-34 Some recent exceptions include Sebastian Conrad, Globalization and the Nation in Imperial Germany, trans. Sorcha O’Hagan (Cambridge: Cambridge University Press, 2010); Peter Gattrell, The Making of the Modern Refugee (Oxford: Oxford: University Press, 2013), as well as works that position themselves as 'global histories' but deal extensively with migration, such as Marilyn Lake, Drawing the Global Colour Line: White Men's Countries and the International Challenge of Racial Equality (Cambridge: Cambridge University Press, 2008); and Andrew Zimmerman, Alabama in Africa: Booker T. Washington, the German Empire, and the Globalization of the New South (Princeton: Princeton University Press, 2010).

23 A few examples: Ulrich Herbert, A History of Foreign Labour in Germany, 1880-1980: Seasonal Workers, Forced Laborers, Guest Workers (Cambridge: Cambridge University Press, 1997); Rita Chin, The Guest Workers Question in Postwar Germany (New York: Cambridge University Press, 2009); Gérard Noiriel, The French Melting Pot: Immigration, Citizenship, and National Identity, trans. Geoffroy de Laforcade (Minneapolis: University of Minnesota Press, 1996); and Mary Dewhurst Lewis, Boundaries of the Republic: Migrant Rights and the Limits of Universalism in France, 1918-1940 (Stanford, CA: Stanford University Press, 2007); Karin Hunn, Nächstes Jahr kehren wir zurück ... Die Geschichte der türkischen 'Gastarbeiter' in der Bundesrepublik (Göttingen: Wallstein Verlag, 2005).

24 For a concise discussion of the definition of global history, see Sebastian Conrad, What Is Global History? (Princeton: Princeton University Press, 2015). Some important works in this direction include Jan Lucassen and Leo Lucassen, Globalising Migration History: The Eurasian Experience (Leiden: Brill, 2014); Dirk Hoerder, Elise van Nederveen Meerkerk and Silke Neunsinger, Towards a Global History of Domestic and Caregiving Workers (Leiden: Brill, 2015); and Hoerder, Cultures in Contact; Agnes Bresselau von Bressensdorf, ed., Über Grenzen: Migration und Flucht in globaler Perspektive seit 1945 (Göttingen: Vandenhoeck \& Ruprecht, 2019).

25 Lynn Hunt, Writing History in the Global Era (New York: W.W. Norton, 2015). 
broader range of geographic and social vantage points, potentially altering foundational narratives in the process. As Jürgen Osterhammel has argued, 'for vast areas, the global social history of the nineteenth century is identical with the history of migration and closely bound up with the history of diaspora formation and the new frontiers resulting from it'. ${ }^{26}$ The history of migration and mobility enables us to study global history from the perspective of Turkish and Vietnamese 'guest workers' in central Europe; post-colonial migrants from South Asia in Britain or from North Africa and Southeast Asia in France; or Polish and Italian agricultural workers in North and South America. It illuminates personal, familial, political and cultural forces that have shaped globalisation alongside economic factors.

Equally important, the study of European migration in a global frame further enriches and complicates our notion of who and what is 'European'. Rita Chin and Paul Betts have explored how Europeans on the right (and some on the left) came to define the ideal of 'Europe' or 'European civilisation' in opposition to Islam and Muslim migrants beginning in the 1980s. It has been mostly forgotten that Islam rarely figured prominently in discussions of migration in West Germany before the 1980s (as opposed to France, where it was more consistently a theme of discussion about the potential and limits of assimilation). Rather, southern Europeans were considered to be the most problematic migrants in Germany. But as Betts argues, 'In the 1970s and 1980s the physical and mental borders of Europe were being redrawn, and voices from both halves of the continent expressed concern about the vulnerability to foreign ideas and people from the developing world. ${ }^{, 27}$ Of course, policies claiming to defend 'Europe' from Islam ignore the centuries-long presence of Muslims in Europe, especially in the Balkans and southern Europe. ${ }^{28}$

This work is a crucial contribution to the history of the idea of Europe. When we look at migrants' experiences, we can also see how migration itself has repeatedly called into question the definition of who is 'European'. Non-Muslim settlers in Algeria were often identified as 'Europeans' before decolonisation, but once they arrived in metropolitan France, their Frenchness and Europeanness were called into question. Interestingly, German expellees from Eastern Europe who 'returned' to West Germany after the Second World War faced the same scepticism about their Germanness. ${ }^{29}$ Pamela Ballinger shows a similar dynamic at work among 'repatriates' from Italian colonies and borderlands after the Second World War, who were regarded as dubious Italians. ${ }^{30}$ Michelle Kahn's work on Turkish migrants to postwar Germany meanwhile demonstrates that Turks were often seen as more German than Turkish once they returned home (which they did often, either permanently or for vacations). In all of these cases, the very act of moving upset the status of migrants as 'Europeans'. Kahn builds on Michael Geyer's claim that German history should include all places where Germans dwell to suggest that it should also include wherever they travel. Considering Turkish migrants to be 'Germanised', she suggests that Turkey and all of the spaces through which Turkish migrants travelled on their way to and from Germany are spaces of return migration and therefore also a part of Central European history. ${ }^{31}$ If we extend this argument to European history, and analyse multi-directional

26 Jürgen Osterhammel, The Transformation of the World: A Global History of the Nineteenth Century, trans. Patrick Camiller (Princeton: Princeton University Press, 2014), 749.

27 Paul Betts, Ruin and Renewal: Civilizing Europe after World War II (New York: Basic Books, 2020), 428; Rita Chin, The Crisis of Multiculturalism in Europe (Princeton: Princeton University Press, 2017); Stokes, Fear of the Family; Naomi Davidson, Only Muslim: Embodying Islam in Twentieth-Century France (Ithaca, NY: Cornell University Press, 2012).

28 Emily Greble, Muslims and the Making of Modern Europe (Oxford: Oxford University Press, 2021).

29 Yann Scioldo-Zürcher, Devenir métropolitain. Politique d'intégration et parcours de rapatriés d'Algérie en métropole (19542005) (Paris: Editions EHESS, 2010); Todd Shepard, The Invention of Decolonization: The Algerian War and the Remaking of France (Ithaca, NY: Cornell University Press, 2008). For a comparative perspective on German expellees and French pieds noirs, see the collected essays in Manuel Borutta and Jan C. Jensen, eds., Vertriebene and Pieds-Noirs in Postwar Germany and France: Comparative Perspectives (Houndmills: Macmillan, 2016).

30 Pamela Ballinger, The World Refugees Made: Decolonization and the Foundation of Postwar Italy (Ithaca, NY: Cornell University Press, 2020), ch. 4.

31 Michelle Lynn Kahn, 'Rethinking Central Europe as a Migration Space', Central European History, forthcoming; for previous works questioning the boundaries of German history see Michael Geyer, 'Where Germans Dwell: Transnationalism 
influences, the field becomes truly global. I see this less as a Eurocentric colonisation of other fields of history and more of a recognition that the boundaries of Europe have always been politically constructed - and that 'European civilisation' was built upon labour, commodities, wealth and cultural and social influences from the rest of the world.

European migration history and global history could enrich one another further by examining relationships between forms of mobility that are often studied in isolation. Migration historians still often analyse 'networks' of migration. These are often segmented either by region (Atlantic, Pacific, Indian Ocean) or by 'type' (slaves, economic migrants, refugees), as if these groups are easily distinguishable. ${ }^{32}$ In his 779-page account of 'world migrations in the second millennium', Dirk Hoerder is particularly attentive to interactions between what he calls 'migration systems'. He cites the example of textile production, in which 'Manchester's cloth manufacture competed with factories in New England, Bombay and Łódż, and was connected to cotton plantations in the US South, Egypt and Uganda. All were destinations of labour migrants with different standards of living and wages. ${ }^{33}$ This example suggests the rich possibility of exploring interconnected global markets for migrant labour in the twentieth century. It also enables us to study labour as a focal point of conflict over migration, since so much political debate around migration in the past and present revolves around the fear of migrants allegedly 'taking' jobs from local workers or depressing wages and job conditions.

Hoerder's work offers an invaluable and wide-ranging analysis of migration in a global context, but we could go further. Adam McKeown has argued persuasively that the 'systems' approach elides the extent to which regional migration networks were themselves a product of global historical processes. 'The segmentation of global migration into different systems, which has facilitated the ability to focus only on transatlantic migration and ignore the rest of the world, was as much a consequence of political intervention into migration as of economic processes,' he maintains. 'A global perspective on migration provides insight not only into the global reaches of an expanding industrial economy, but also into how this integrative economy grew concurrently with political and cultural forces that favored fragmentation into nations, races, and perceptions of distinct cultural regions. ${ }^{34}$ In other words, studying migration in a global and relational framework renders visible the political decisions that shaped seemingly anonymous forces of 'globalisation'.

By taking a global perspective, McKeown's work challenges several assumptions that traditionally structure transatlantic and European migration histories. He upends the view that most Asian migrants in the nineteenth and early twentieth centuries were indentured or forced migrants, that they were fundamentally different from European migrants. He also challenges the periodisation long favoured by historians of transatlantic migration. By looking beyond transatlantic mobility, we see that migration restrictions multiplied well before 1914 and that mass migration continued beyond the outbreak of the First World War, declining significantly only with the onset of the Great Depression. Most significantly, McKeown joins historians of slavery in historicising the very distinction between 'forced' and 'free' labour and mobility as a product of nineteenth-century efforts to distinguish 'white' labour migration from the migration of African slaves or Asian indentured servants, and in the context of abolition movements. ${ }^{35}$ His work demonstrates how a deep understanding of mobility and migration outside of Europe, in a global framework, can fundamentally transform histories of European mobility and migration.

in Theory and Practice', German Studies Association Newsletter, 31, 2 (2006), 29-37; James Sheehan, 'What is German History? Reflections on the Role of the Nation in German History and Historiography', Journal of Modern History, 53, 1 (1981), 1-23.

32 For a recent history of this distinction, see Karen Akoka, L'asile et l'exil. Une histoire de la distinction réfugiés/migrants (Paris: La Découverte, 2020). On the German context, see Volker Ackermann, Der 'echte' Flüchtling: Deutsche Vertriebene und Flüchtlinge aus der DDR, 1945-1961 (Osnabrück Universitätsverlag Rasch, 1995); on the emergence of this distinction in international law after the Second World War, see G. Daniel Cohen, In War's Wake: Europe's Displaced Persons in the Postwar Order (New York: Oxford University Press, 2012).

33 Hoerder, Cultures in Contact, 10.

34 Adam McKeown, 'Global Migration, 1846-1940', Journal of World History, 15, 2 (2004), 155-6.

35 Ibid. 


\section{Migration, Mobility and Empire}

Taking a relational and global approach to European migration puts the interconnected histories of migration and empire centre-stage. The shadow of empire has loomed over almost every discussion of migration in the past two centuries, even in places not typically considered imperial powerhouses. Empires large and small have expanded and prospered through the movement and exploitation of slaves, indentured servants and native labour. The deportation of convicts, paupers and orphans was key to the population and 'productivisation' of both overseas and land empires such as Russia and the United States. In her study of migrants from the pre-unification state of Piedmont-Sardinia in Peru, Lucy Riall shows that global ambitions in the region predated the nation-state and built on early modern trade networks, as entrepreneurs pursued commercial and scientific interests in the Americas. ${ }^{36}$ Later in the nineteenth and early twentieth centuries, many European state officials and nationalist activists saw emigrants as raw human material for the construction and expansion of nations and empires. They promoted new ideals of diaspora that would link migrants scattered around the world to real or imagined homelands. These diasporic empires were built not only through the circulation of objects, print culture, letters and remittances but also through the expansion of consular services, state-funded and private welfare initiatives and schools. ${ }^{37}$

Beginning in the late nineteenth century, several countries that had large numbers of emigrants, including Italy, Germany and Poland, invoked their diasporas in order to make claims for more formal colonial expansion. In a 1939 appeal to the League of Nations, for example, the Polish delegation proposed that the league's colonial mandate system be extended to Africa, and that African colonies be redistributed among European states according to 'their capacity for colonisation and their real economic and demographic needs'. Of course, the Poles claimed to be at the top of the list on both counts. In terms of colonising capabilities, Polish emigrants had already 'provided the proof of their abilities, by transforming the virgin forests and uncultivated plains of Brazil, Argentina, Canada, and Siberia into arable land ... In particular the tenacity of labour, love of the land and pioneering spirit of the Polish peasant has rendered him invaluable. ${ }^{38}$

The history of settler and emigrant colonialism highlights critical links between Europe's global history, colonial histories and migration histories. James Belich argues that a 'settler revolution' between 1789 and 1920, characterised by an 'explosive' cycle of boom, bust and rescue, propelled the rise of what he calls the 'Anglo-world'. Belich seeks to explain what he sees as Anglo-American exceptionalism, but there was nothing exceptional about the link between emigration, industrialisation and colonialism. Emigrant settlers altered and created new economies, environmental landscapes, religious practices and institutional and legal frameworks around the world; they introduced technologies, diseases, ideas and hierarchical economic, racial, gender and political systems, the legacies of which have long outlasted formal colonialism. ${ }^{39}$ And as post-colonial scholars have argued for decades, settler

36 Lucy Riall, 'Hidden Spaces of Empire: Italian Colonists in Nineteenth-century Peru', Past and Present (May 2022).

37 On migrant or diaspora colonialism, see especially Mark Choate, Emigrant Nation: The Making of Italy Abroad (Cambridge, MA: Harvard University Press, 2008); Conrad, Globalization and the Nation; Krista O'Donnell, Renate Bridenthal and Nancy Reagin, The Heimat Abroad: The Boundaries of Germanness (Ann Arbor: University of Michigan Press, 2015); Glenn Penny, 'Material Connections: German Schools, Things, and Soft Power in Argentina and Chile from the 1880s through the Interwar Period', Comparative Studies in Society and History, 59, 3 (2017), 519-49; Zahra, The Great Departure. On the 'diasporic empire' see Benjamin Van Zee, 'Polish Nationalists, German Missionaries and Jewish Philanthropists: An Entangled History of Central European Diasporic Imperialism and the British Empire in the Interwar World', $\mathrm{PhD}$ dissertation, University of Chicago, forthcoming). On the role of China's diaspora in the making of modern China, see Shelly Chan, Diaspora's Homeland (Durham, NC: Duke University Press, 2018).

38 Memorandum sur la question de l'extension aux territoires coloniaux d'Afrique des principes des mandats, 23 May 1939 , Sig. 9737, B26147, MSZ, Archiwum akt nowych, Warsaw.

39 On the rise of the 'Anglo-American' world through settler colonialism, see James Belich, Replenishing the Earth: The Settler Revolution and the Rise of the Angloworld, 1783-1939 (Oxford: Oxford University Press, 2009). On settler colonialism see also the contributions to Caroline Elkins and Susan Pedersen, eds., Settler Colonialism in the Twentieth Century: Projects, Practices, Legacies (New York: Routledge, 2005). On the link between German emigration to the Americas and 
colonies profoundly transformed European metropoles through the importation of commodities, techniques of rule and racial and gender hierarchies from colony to metropole. Emigrants and settler colonists also transformed Europe because they so often returned home. At the high point of transatlantic migration in the early twentieth century, thirty to forty per cent of emigrants eventually returned, often with dollars in their pockets and new experiences and worldviews. Later in the twentieth century, European settlers (and their supporters) returned en masse from places like Libya, Algeria and Rhodesia (sometimes to 'homelands' they had never seen) in the wake of decolonisation. ${ }^{40}$

Settler colonies left others with lasting global legacies. Marilyn Lake and Henry Reynolds argue persuasively that migration and the threat of revolt against empire created and consolidated a transnational, imagined community of 'whiteness', a 'colour line' that divided the globe into a 'white' and 'non-white' world. The creation of this 'global colour line' became a keystone of migration policies in former British settler colonies like the United States, South Africa and Australia. As Mae Ngai has shown, US migration laws in the early twentieth century effectively created a distinction between 'ethnicity' (a term used to designate differences of nationality between 'white' Europeans) and 'race' - used to describe non-Europeans who were not endowed with a nationality. Ngai's book is rarely read as a work of global history, but it is an important chapter in the history of how Europe and whiteness itself were created through the regulation of global migration. ${ }^{41}$

Imperial concerns and the formation of multiple (and often unstable) 'colour lines' had an impact well beyond the British Empire, which is the most common setting for global histories. Migration policies in central, eastern and southern Europe were motivated by fears that emigrants would become the new 'slaves' of North and South America - but also by a desire to build global empires through migration. The legacy of empire shaped mobility and migration long after decolonisation, moreover, as colonial subjects and settlers migrated more easily within imperial or former imperial borders, and as post-colonial migrants were drawn to places with a familiar language and culture, or where family members or neighbours were already settled.

The era of post-colonial mobility between European empires and former colonies was fleeting, however. A sense of European identity from below was created in the post-war period in part by European backpackers criss-crossing the continent, as Richard Ivan Jobs shows. ${ }^{42}$ But the ideal of a borderless Europe and the institution of the European Union, with its provisions for freedom of mobility, did not disappear. On the contrary, it developed alongside state attempts to close down longstanding networks of circulation and migration between European states and former colonies. In France, for example, the process of decolonisation entailed actively disavowing the notion that Algerians and other former French colonial subjects could ever become French. As Naomi Davidson has argued, Islam was increasingly racialised in post-colonial France, and Muslims were defined as inherently unassimilable to the French nation. Udi Greenberg has likewise highlighted the ways that European integration replaced other forms of European overseas

Germany's industrialisation and globalisation, see Benjamin Hein, 'Emigration and the Industrial Revolution in German Europe, 1820-1900', PhD dissertation, Stanford University, 2018.

40 On migration and decolonisation see Jordanna Bailkin, The Afterlife of Empire (Berkeley: University of California Press, 2012); Scioldo-Zürcher, Devenir métropolitain; Ballinger, The World Refugees Made; Andrea Smith, ed., Europe's Invisible Migrants: Consequences of the Colonists' Return (Amsterdam: Amsterdam University Press, 2002); Jean-Louis Miège and Colette Dubois, eds., L'Europe rétrouvée: Les migrations de la décolonisation (Paris: L'Harmattan, 1994); Amelia H. Lyons, The Civilizing Mission in the Metropole: Algerian Families and the French Welfare State during Decolonization (Stanford: Stanford University Press, 2013); Elizabeth Buettner, Europe after Empire: Decolonization, Society, and Culture (Cambridge: Cambridge University Press, 2016); Félix Germain, Decolonizing the Republic: African and Caribbean Migrants in Postwar Paris, 1946-1974 (East Lansing: Michigan State University Press, 2016); Minayo Nasiali, Native to the Republic: Empire, Social Citizenship, and Everyday Life in Marseille since 1945 (Ithaca, NY: Cornell University Press, 2016); Kennetta Hammond Perry, London is the Place for Me: Black Britons, Citizenship and the Politics of Race (New York: Oxford University Press, 2016).

41 Lake and Reynolds, Drawing the Global Color Line; and Mae Ngai, Impossible Subjects: Illegal Aliens and the Making of Modern America (Princeton: Princeton University Press, 2014).

42 Richard Ivan Jobs, Backpack Ambassadors: How Travel Integrated Europe (Chicago: Chicago University Press, 2017). 
engagement. ${ }^{43}$ A similar process took place in Britain after decolonisation, as migrants and refugees from places like Eastern Europe were soon considered more assimilable and desirable than postcolonial or non-European migrants. ${ }^{44}$ Making Europe into a zone of internal free mobility - and especially the establishment of the Schengen Area in 1995 - meant creating an Iron Curtain around the continent, often referred to as 'Fortress Europe' by critics of EU migration policy. ${ }^{45}$

Legacies of these attitudes remain pervasive. In both the past and present, East European migrants have been seen as 'good' or acceptable migrants within Europe by virtue of their whiteness or religion, while migrants from outside Europe have been deemed unassimilable. ${ }^{46}$ The violence directed toward Polish migrants in Britain in the wake of the Brexit vote demonstrates the ongoing precarity of East Europeans' status as 'Europeans'. Yet European and non-European migrants have been compared and ranked throughout European and global history.

Even the history of intra-European migration was shaped in a global context. In the late nineteenth century, Austro-Hungarian and Italian officials often sought to encourage seasonal or intra-European migration as an alternative to emigration overseas. This was both because seasonal migrants were more likely to return home (or at least send their pay cheques home) and because officials feared that migrants to North and South America would be treated no better than slave or colonial labour. In the 1940s and 50s (and beyond), the migration of refugees from Eastern to Western Europe became a critical battleground in the global Cold War. Today, East European governments are arguably most hostile to refugees and immigration from outside of Europe. This is not because there is no history of migration or multiculturalism in these societies (there is), but because having gained, at long last, the status of white Europeans and freedom of mobility within Europe, East Europeans may be the most invested in protecting their white privilege and keeping non-Europeans out. ${ }^{47}$

\section{Towards a New European History of Mobility?}

Beyond writing relational histories of migration, and better interweaving the histories of migration and empire, how could we further integrate migration history, European history and global history? This is not merely an intellectual dilemma: it is also an economic, logistical, linguistic and institutional challenge. Multi-sited archival research is expensive and time-consuming. Writing truly global histories is often a privilege reserved for those with the time, resources and freedom to travel extensively. It also generally requires extensive language training. One step is to make global history a more feasible and accessible undertaking from an institutional and financial perspective. This would entail redistributing research funds to scholars who are not in the traditional centres of academic power and, for granting agencies, funding more multi-sited work.

At the same time, it is worth considering strategies for writing global histories and migration histories from the perspective of particular localities, nation-states, regions or individuals. Some recent

43 Shepard, The Invention of Decolonization; Naomi Davidson, Only Muslim: Embodying Islam in Twentieth Century France (Ithaca, NY: Cornell University Press, 2012; Udi Greenberg, 'Protestants, Decolonization, and European Integration, 1885-1961', Journal of Modern History, 89, 2 (2017), 314-54.

44 Davidson, Only Muslim; Jordanna Bailkin, The Afterlife of Empire; Kathleen Paul, Whitewashing Britain: Race and Citizenship in the Postwar Era (Ithaca, NY: Cornell University Press, 1997); Ethan Katz, The Burdens of Brotherhood: Jews and Muslims from North Africa to France (Cambridge Cambridge University Press, 2015); Emily Marker, 'France Between Europe and Africa: Youth, Race, and Envisioning the Postwar World, 1940-1960', PhD dissertation, University of Chicago, 2015; Michael Kozakowski, 'From the Mediterranean to Europe: Migrants, the world of work, and the transformation of the French Mediterranean, 1945-1974', PhD dissertation, University of Chicago, 2014.

45 See for example Matthew Carr, Fortress Europe: Dispatches from a Gated Continent (New York: C Hurst \& Co., 2016).

46 On whiteness in migration history, see Matthew Frye Jacobsen, Whiteness of a Different Color: European Immigrants and the Alchemy of Race (Cambridge, MA: Harvard University Press, 1998); Catrin Lundström, White Migrations: Gender, Whiteness and Privilege in Transnational Migration (London: Palgrave Macmillan, 2014).

47 On Cold War migration, see among others Dariusz Stola, Kraj bez wyścia? Migrace z Polski 1949-1989 (Warsaw: IPN, 2010); Lewis S. Siegelbaum and Leslie Page Moch, Broad is My Native Land: Repertoires and Regimes of Migration in Russia's Twentieth Century (Ithaca, NY: Cornell University Press: 2014). On internal migration in Austria-Hungary in relationship to emigration, see especially Annemarie Steidl, On Many Roads. Internal, European, and Transatlantic Migration in the Habsburg Monarchy, 1850-1914 (West Lafayette, IN: Purdue University Press, 2020). 
monographs and dissertations offer models for what this work could look like. One thing they have in common is that they link multiple scales of analysis, from the individual migrant, to the refugee camp or steamship, to the nation-state, to global imperial and post-imperial politics. For example, Pamela Ballinger's The World Refugees Made shows how the process of post-fascist decolonisation in Italy, which set into motion at least 750,000 people, contributed to the making of a new international refugee regime as well as the remaking of a post-fascist Italy. As Italian and international officials classified refugees as either Italian nationals being 'repatriated' to Italy or as 'foreign' refugees, they simultaneously redefined the meaning of Italianness and of refugeedom in ways that resonated far beyond the immediate setting of post-war Italy. ${ }^{48}$

Charles Fawell's dissertation on French steamship travel on the Suez offers another model for bringing European history, the history of mobility and global history into conversation. The weeks or months spent by soldiers, travellers and workers aboard steamships, he shows, represented far more than lost time between departure and arrival. Instead, steamships were 'an imperial crisis in motion'. Shipping companies were charged with creating and enforcing imperial racial and social hierarchies that threatened to become blurred on long sea journeys. They navigated tricky issues of imperial and national sovereignty in the maritime spaces between empires. Long hours spent on deck, in dining halls, and in smoking rooms provided soldiers and officials with ample opportunities to form elite social networks and exchange knowledge about imperial rule. Contrary to narratives that link the steamship to the acceleration of global mobility, Fawell demonstrates how steamships frequently controlled and limited the mobility of particular kinds of people, goods and diseases. The steamship can thus shed light on immobility as well as acceleration. ${ }^{49}$

Going forward, we should pay even more attention to immobility and anti-globalism, as well as to 'failed' migrations. Osterhammel notes that 'global historians sometimes see only mobility, networking, and cosmopolitanism. Yet both groups should be of interest to us: the migrant minorities and the settled majorities visible in all nineteenth-century societies. ${ }^{50}$ Refugees, stateless persons and others who have been trapped by restrictions on immigration and emigration illuminate the non-teleological rhythm of globalisation, which is full of stops and starts, openings and closings, arrivals and departures. Ther rightly argues that historians of migration need to take account of these 'failed' attempts to flee. ${ }^{51}$ Many twentieth-century efforts to expand empires or settle land ('internal colonisation') were motivated in part by a desire to acquire independence from the global economy (and make emigration unnecessary) by achieving greater national self-sufficiency in food and energy production. Many global humanitarian and international organisations in the twentieth century were responding to crises created by immobility as well as by movement. ${ }^{52}$ It would also be worth considering the moments of European history that have been most shaped by mass migration, such as the late nineteenth century transatlantic exodus or the Second World War, from the perspective of individuals who stayed put or returned home. The experiences of sedentary populations, those 'left behind' in a more mobile world, have also shaped attitudes and policies toward migrants and migration.

What would it look like, finally, to highlight the global history of migration in and out of the Bohemian lands, with which I began this essay? It could mean placing mid-nineteenth-century emigration in the context of the 1848 revolutions and their global reverberations; considering policies toward late-nineteenth and early-twentieth-century emigration in light of Austria-Hungary's anxieties

\footnotetext{
48 Ballinger, The World Refugees Made.

49 Fawell, In-Between Empire.

50 Osterhammel, The Transformation, 117; and Richard Drayton and David Motadel, 'The Futures of Global History', Journal of Global History, 13 (2018), 1-21.

51 On 'failed' refugees, see Ther, The Outsiders, 20. On departures from Israel, see Ori Yehudai, Leaving Zion: Jewish Emigration from Palestine and Israel after World War II (Cambridge: Cambridge University Press, 2020).

52 Bruno Cabanes, The Great War and the Origins of Humanitarianism, 1918-1924 (New York: Cambridge University Press, 2014); Mark Mazower, Governing the World: The History of an Idea (New York: Penguin, 2012); Peter Gatrell, Free World? The Campaign to Save the World's Refugees, 1956-63 (Cambridge: Cambridge University Press, 2011); Gerard D. Cohen, In War's Wake: Europe's Displaced Persons in the Postwar Order (Oxford: Oxford University Press, 2012).
} 
about global status; analysing the global reception of Jewish refugees in the context of contemporary colonial politics; and highlighting links between post-war ethnic cleansing in East Central Europe and simultaneous population 'transfers' in South Asia and Palestine/Israel. It could draw our attention to the post-socialist 'traffic in women' from Central and Eastern Europe, or the robust new industry of 'fertility tourism' that has developed in the Czech Republic, as couples from Europe and North America seek out affordable 'white' egg donors. ${ }^{53}$ At the very least, it would involve situating the rise of anti-migrant, right-wing populist parties in Europe today in a longer history of (often unacknowledged or forgotten) migration and opposition to migration.

Ultimately, the European history of migration has the potential to highlight relationships between global structures, regional and national histories and individual decisions to stay or go. It can shine a spotlight on human stories, people and places not often associated with global history. Most importantly, it can put to rest polemical claims that there is a need to protect 'European civilisation' from the changes wrought by migration. This is because there is no 'European civilisation' that was not made by migrants or through migration.

\footnotetext{
53 Heléna Tóth, An Exiled Generation: German and Hungarian Refugees of Revolution, 1848-1871 (New York: Cambridge University Press, 2014); Ulf Brunnbauer, Globalizing Southeastern Europe. America, Emigrants and the State since the late 19th Century (Lanham, MD: Lexington, 2016); Gatrell, The Making of the Modern Refugee; A. Dirk Moses, 'Partitions and the Sisyphean Making of Peoples', Refugee Watch, 46 (2015), 36-50; Anca Parvulescu, The Traffic in Women's Work: East European Migration and the Making of Europe (Chicago: University of Chicago Press, 2014), 40; Amy Speier, Fertility Holidays: IVF Tourism and the Reproduction of Whiteness (New York: NYU Press, 2016); and Hoerder, Towards a Global History of Domestic and Caregiving Workers.
}

Cite this article: Zahra T (2022). Migration, Mobility and the Making of a Global Europe. Contemporary European History 31, 142-154. https://doi.org/10.1017/S0960777321000758 